\title{
Kommentar
}

\section{«Så heldig du har vært!»}

Asbjørn Rotevatn gir oss et verdifullt innblikk i hvordan livet etter en hjernehinneblødning fra et aneurisme kan oppleves. Da blødningen rammet som lyn fra klar himmel forsto han selv alvoret umiddelbart og sørget for å komme raskt til sykehus. Han beskriver videre en reblødning fra aneurismet umiddelbart etter ankomst $i$ akuttmottaket samt at han var i ferd med å utvikle et akutt vannhode. Det ble utført en rask, effektiv og skånsom endovaskulær tetning av aneurismet og cerebrospinalvæske ble drenert slik at sekundære skadevirkninger på hjernen ble unngått i størst mulig grad.

\section{God akuttbehandling}

Behandlingen av akutte aneurismeblødninger er nærmest blitt revolusjonert i løpet av de siste 20 årene. Med moderne behandlingsparadigmer, slik som hans skildring gir en god fremstilling av, er overlevelsen og utfallet bedret betydelig. Pasientens situasjon etter blødningen blir ofte kategorisert ved hjelp av en standardisert skala som Glasgow Outcome Score (GOS) eller modifisert Rankins skår, hvor et godt utfall (GOS-skår 5 og 4, Rankins skåre 0-2) er, enkelt sagt, karakterisert ved evnen til å kunne leve uavhengig. GOS-skår eller Rankins skår er nokså grove måleinstrumenter som ikke gjenspeiler godt nok hvordan et menneske fungerer eller opplever hverdagen sin. Møter pasienten til første kontroll hos behandlende lege (som regel tre måneder etter blødningen), inkluderer standardopplegget nevrologisk status og bildediagnostikk. Heldigvis har mange av dem som overlever subaraknoidalblødning, ingen åpenbare nevrologiske forstyrrelser. Behandlende lege vil som oftest vurdere dette som et godt utfall - rimelig nok. Pasienten vil ofte også fremstå som glad og opprømt over å ha overlevd med et så godt resultat. «Det kunne jo ha gått mye verre, jeg har vært heldig,» er uttalelser jeg ofte har hørt. Det blir da ofte også svaret på spørsmålet: «Hvordan har du det?» Er det lov å si noe annet enn at man har det bra når man nærmest har unnsluppet døden?

\section{Problemene etterpå}

Denne første gleden kan noen måneder senere ha gått over i skuffelse når det blir klart at ikke alt er som det var før blødningen. På dette tidspunktet er det mange som forteller om økt trettbarhet, initiativløshet, svekket hukommelse og redusert konsentrasjonsevne, vanskeligheter med å forholde seg til flere stimuli og intoleranse for støy. Mange opplever større følelsesmessige svingninger og tar lettere til tårene enn tidligere. Særlig initiativløsheten og trettbarheten oppleves som et problem for pasienten og omgivelsene. Det danner seg etter hvert en diskrepans mellom forventningene og mulighetene til å kunne fungere $\mathrm{i}$ hverdagen. Mange pasienter blir fortvilet og føler seg utsatt for press fra både pårørende og legen fordi «jeg virker så frisk, ingen kan se på meg at jeg sliter». Noen føler seg presset ut $\mathrm{i}$ arbeidslivet uten mulighet til å kunne mestre det. Ett år etter en relativt ukomplisert blødning fra et aneurisme på a. communicans anterior er kun drøye $50 \%$ tilbake i arbeid, mange med tilrettelegging av arbeidsoppgavene eller i et annet type arbeid enn det de tidligere hadde. De «usynlige» plagene beskrevet ovenfor har altså betydelige psykososiale konsekvenser og reduserer livskvaliteten målbart. Rotevatn fikk også merke dette da han prøvde seg på jobben igjen. Heldigvis hadde han en forståelsesfull fastlege som attpåtil var oppmerksom på mulige kognitive konsekvenser av blødningen.

\section{Nevropsykologisk utredning}

Nevropsykologisk undersøkelse er nyttig når man skal analysere og kvantifisere problemene som oppstår etter en aneurismeblødning. Ved hjelp av slike tester kan man finne ut hvilke kognitive ferdigheter som er rammet og ikke minst hva som fungerer bra og som kan gi et godt utgangspunkt i pasientens fremtidige arbeidsliv. Nevropsykologisk undersøkelse spiller også en viktig rolle i utredningen for mulig utvik- ling av sekundær hydrocephalus etter subaraknoidalblødning. Rehabiliteringsopplegget kan bedre skreddersys for den enkelte når den nevropsykologiske profilen er kjent. I dag er denne type undersøkelser ikke del av standard oppfølgingsopplegget hos pasienter med et såkalt godt resultat. Selv om det ikke er avklart om nevropsykologisk kartlegging ville ha tilbakeført flere pasienter raskere og smidigere til et normalt sosialt og yrkesrelatert liv, kan den i det minste synliggjøre de «usynlige» plagene og dermed ikke bare gi en bekreftelse til pasienten som fremmer mestring, men også være et viktig redskap i prosessen med å vurdere eventuelle permanente trygdeytelser.

Det er behov for $ø k t$ bevissthet omkring de kognitive og følelsesmessige konsekvensene av aneurismeblødninger både i spesialisthelsetjenesten og i primærhelsetjenesten. Et godt første tiltak for å oppnå dette kan være å senke terskelen for å rekvirere nevropsykologisk utredning.

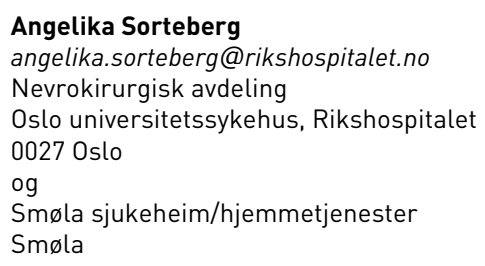

Manuskriptet ble mottatt 24.3. 2009 og godkjent 26.3. 2009. Medisinsk redaktør Erlend Hem. 